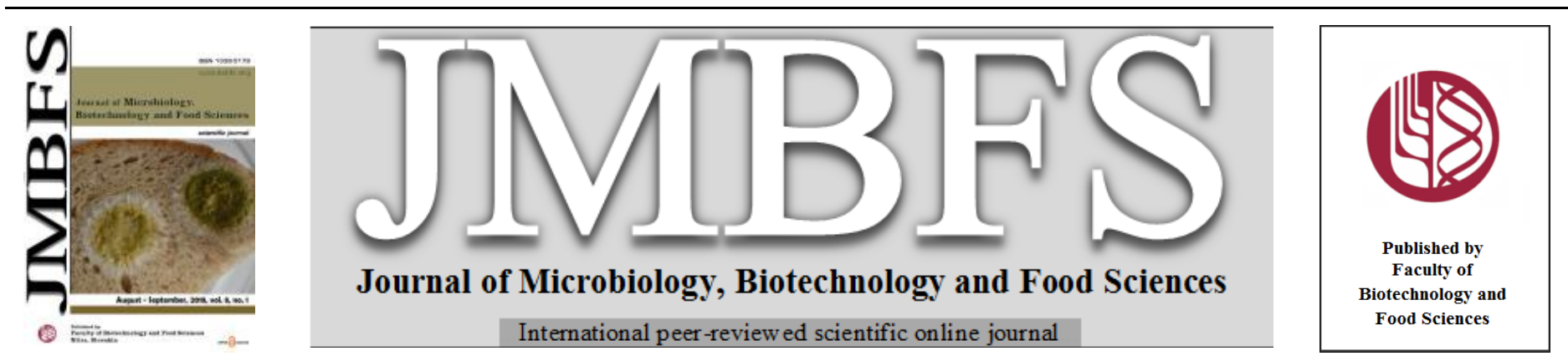

\title{
SEROLOGICAL AND MOLECULAR DETECTION OF VIRUSES INFECTING FIG TO IDENTIFY THE VIRUS-FREE PLANTS
}

\author{
Hemaid Ibrahim Ahemaidan Soliman
}

$\operatorname{Address}(e s)$ :

Plant Genetic Resources Department, Desert Research Center, El-Matariya 11753, Cairo, Egypt.

*Corresponding author: hahemaid@yahoo.com

doi: 10.15414/jmbfs.2018.8.1.726-731

\section{ARTICLE INFO}

Received 9. 3. 2018

Revised 10. 6. 2018

Accepted 9. 7. 2018

Published 1. 8. 2018

Regular article open $\mathcal{O}$ access

\begin{abstract}
Fig (Ficus carica L.) is one of the old and the most common fruit tree grown in all the Mediterranean countries, which is among those exposed to diseases and pathogens. A recent investigation indicated that fig mosaic disease was the main pathogenic agent. In this study, field surveys were conducted in different areas of Egypt. A total of 300 leaf samples were collected randomly from symptomatic and symptomless fig trees of six cultivars, and tested by RT-PCR for the presence of Fig mosaic virus (FMV), Fig leaf mottleassociated virus 1 (FLMaV-1), Fig leaf mottle-associated virus 2 (FMMaV-2), Fig mild mottle-associated virus (FMMaV) and Fig latent virus 1 (FLV-1), using specific sets of primers. About $84 \%$ of the samples tested were found to be infected by at least one virus. FLMaV-1 was the prevailing virus with a (78.3\%) incidence followed by FMV (73.7\%), FLMaV-2 (50\%), FLV-1(40.3\%) and FMMaV $(35 \%)$. The highest infection rate was observed in Sultani, Asuani and Adasi-Ahmer (100\%), followed by Kahramani (80\%), Kadota $(64 \%)$ and Black Mission (60\%).Ultra thin section for infected fig plants showed a large double-membrane particles (DMPs) 100-150 $\mathrm{nm}$ in diameter were located in the cytoplasm of parenchyma cells. Fig mosaic virus-specific antiserum raised in rabbits, proved useful for its detection in fig tissues. The plantlets from meristem tip tissue culture were transplanted successfully. FMV could be detected through DAS-ELISA in the virus-free fig plantlets.
\end{abstract}

Keywords: Ficus carica, fig mosaic disease, virus detection, RT-PCR, DAS-ELISA, electron microscopy

\section{INTRODUCTION}

The fig (Ficus carcia L.) is one of the earliest cultivated fruit trees and its cultivation has spread to many parts of the world, especially in the Mediterranean, Middle East and naturalized in many places. Nowadays it is an important crop worldwide. Fig is a desert plant cultivated in Egypt especially north coast of the western desert which extends from the Alexandria to the Marsa Matrouh. Lately, the plants showed a mosaic symptom associated with a great loss in the yield. The causal agent of the disease is associated with the high population of mites and was identified as fig mosaic virus (Hemaid et al., 2010) Fig mosaic has a wide distribution and has been reported as occurring in the following countries: United States, Turkey, England, Algeria, Tunisia, Syria, Spain, Italy, Jordan, New Zealand, Puerto Rico, Greece, Israel, China, and Australia (Blodgett and Belgin, 1967). Fig mosaic disease (FMD) was first reported in California and symptoms include bright mosaic, spotting and distortion of leaves and mottling, reduction in the size of some fruits and occasional leaf malformation. Symptoms often appear clearly when the tree becomes under heat or water-stresses (Condit and Horne, 1933). Fig mosaic is transmitted in nature by the eriophyid Aceria ficus which is transmitted from plant to plant through wind (Flock and Wallace, 1955) and the virus may be transmitted by vegetative propagation of infected cuttings from diseased trees and by budding or grafting of infected propagative buds or scions to healthy stocks (Blodgett and Belgin, 1967). Recent studies have reported FMD observation, in leaf tissues fig symptomatic of viral particles of different morphology (Serrano et al., 2004). Several viruses infecting fig trees have been reported Fig mosaic virus (Walia et al., 2009; Elbeaino et al., 2009a), Fig leaf mottle-associated virus 1 and 2 (Elbeaino et al., 2006; Elbeaino et al., 2007), Fig mild mottle-associated virus (Elbeaino et al., 2010), Fig latent virus 1 (Gattoni et al., 2009), Fig badnavirus-1 (Tzanetakis et al., 2010), Arkansas fig closteroviruses 1 and 2 (Elbeaino et al., 2011a), Fig fleck-associated virus (FFkaV) and Fig cryptic virus (Elbeaino et al., 2011b) but fig mosaic virus (FMV) is the agent that occurs in symptomatic plants more often than any of the other fig-infecting RNA viruses, and is the major incitant of mosaic. Fig mosaic virus (FMV) is a member of the recently established genus Emaravirus (Adams and Carstens, 2012). The FMV genome consists of segmented (multipartite) negative-sense, single-stranded RNA (Elbeaino et al., 2009a). The genome has long been thought to have four segments, but recently, discovered that FMV genome contains six RNA genome segments (Elbeaino et al., 2009b; Walia et al., 2009; Ishikawa et $\boldsymbol{a l} .$, 2012) and dsRNA isolated from FMD-affected fig trees had revealed a changing number of molecules of up to $7 \mathrm{~kb}$ in length (Acikgöz and Döken, 2003). Each segment has one open reading frame (ORF) (Ishikawa et al., 2013). The first segment, FMV vcRNA 1 (7093 nt), is common to all viruses of genus Emaravirus and codes for the virus's $264 \mathrm{kDa}$ RNA dependent RNA polymerase (RdRp). The second segment, vcRNA2, (2252 nt) encodes a $73 \mathrm{kDa}$ putative glycoprotein. FMV vcRNA3 (1490 nt) encodes a 35 $\mathrm{kDa}$ nucleocapsid protein. FMV vcRNA4 (1472 nt) encodes a $40.5 \mathrm{kDa}$ protein with function still unknown (Walia and Falk, 2012). The two most recently discovered segments, RNA5 (1752 nt) encodes a 59 kDa and RNA6 (1212 nt) encodes a $22 \mathrm{kDa}$ these proteins are the unknown function (Elbeaino et al. 2012). All RNA segments possess untranslated regions containing at the 50 and 30 termini a13-nt complementary sequence (Ishikawa et al., 2012).

Ultrastructural studies have shown FM affected plants to have a characteristic cytopathology. The cells of the symptomatic plants contain quasi-spherical, double-membrane-bound particles (DMPs) of 100 to $200 \mathrm{~nm}$ in diameter present in the cytoplasm (Martelli et al., 1993; Appiano et al., 1995). Infection with FMV results in distinct double-membrane bodies or particles, called DMBs or DMPs, 90-200 nm in diameter in the cytosol of infected parenchyma cells (Walia et al., 2009; Caglayan et al., 2009). Immunological assays such as enzymelinked immunosorbent assay (ELISA) have been successfully applied for detection of viruses in different organisms such as plants and insects Clark \& Adams (1977). Two principle methods "direct" and "indirect" depends on antigen-antibody for ELISA test has been used in several virology studies. This assay is visualized by means of a suitable detection system such as an enzymelabeled antibody which reported by Van Regenmortel and Dubs 1993. The most advantage for ELISA test is to test a high number of samples in short time (Clark and Bar-Joseph 1984; Cooper and Edwards, 1986).

In this study we report a preliminary investigation carried out in some fig growing areas of Egypt to assess the presence of FMV, FLMaV-1, FLMaV-2, FMMaV and FLV-1 using molecular tools (RT-PCR), to isolate and identified 
the FMV-infected plant tissues and used meristem culture to regenerate virusfree plants.

\section{MATERIALS AND METHODS}

\section{Field survey and plant material}

To study the distribution of the disease, three hundred samples were collected from naturally infected fig cultivars Asuani, Kadota, Black Mission, Kahramani, Sultani and Adasi-Ahmer. The chosen fifty samples from each cultivar of fig trees are located in Aswan, Kaliobeya, Monoufia, Giza, Sinai Governorates and the Northern West Coast, Egypt, which were selected randomly. Symptoms varied from chlorotic blotches, vein clearing, vein banding, chlorosis, mosaic and chlorotic ringspot, all suggestive of virus-like diseases. All of the samples were assayed by RT-PCR to assess the presence of FMV, FLMaV-1, FLMaV-2, FMMaV, and FLV-1 in Egypt.

\section{Extraction of nucleic acids and RT-PCR}

Total RNAs were extracted from leaves of infected fig trees and healthy controls from in vitro plantlets using the RNeasy kit (Qiagen, Germany) following the manufacturer's instructions. RNA aliquots of $50 \mathrm{ng}$ were used as a template for RT- PCR. The detection of FMV, FLMaV-1, FLMaV-2, FMMaV and FLV-1 in RT-PCR was conducted using one set of specific primers (Table 1), whose nucleotides sequences and use conditions were previously described (Elbeaino $\boldsymbol{e}$ al., 2006; 2007; 2009; 2010; Gattoni et al., 2009). One-step RT-PCR protocol was used in a $25 \mu \mathrm{l}$ reaction volume containing template, $2.5 \mu \mathrm{l}$ of $10 \mathrm{X}$ PCR buffer, $1.1 \mu \mathrm{l}$ of $25 \mathrm{mM} \mathrm{MgCl}, 1.25 \mu \mathrm{l}$ of $0.1 \mathrm{M}$ DTT (dithiothreitol), $0.5 \mu \mathrm{l}$ of $10 \mathrm{mM}$ dNTPs, $1.25 \mu \mathrm{l}$ of specific primer set $(10 \mu \mathrm{M}), 0.25 \mu \mathrm{l}$ of Taq polymerase $(5 \mathrm{U} / \mu \mathrm{l}$; Fermentas, Canada), and $0.035 \mu \mathrm{l}$ of reverse transcriptase (200 units $/ \mu \mathrm{l}$; Fermentas). Reactions were performed at one cycle of $42^{\circ} \mathrm{C}$ for 30 min; 35 cycles of $94^{\circ} \mathrm{C}$ for $30 \mathrm{~s}, 55^{\circ} \mathrm{C}$ for $45 \mathrm{~s}$, and $72^{\circ} \mathrm{C}$ for $1 \mathrm{~min}$; and a final $72^{\circ} \mathrm{C}$ extension for $10 \mathrm{~min}$. PCR products were analyzed by electrophoresis in $1.5 \%$ agarose gels in TrisAcetate-EDTA buffer, stained with ethidium bromide and visualized under UV light.

Table 1 RT-PCR specific primers of five fig-infecting viruses (FMV, FLMaV-1, FLMaV-2,FMMaV and FLV-1)

\begin{tabular}{|c|c|c|c|c|c|}
\hline Virus & Genus & $\begin{array}{l}\text { Amplicon } \\
\text { (bp) }\end{array}$ & Gene & Primer sequence 5'-3' & Reference \\
\hline FMV & Emaravirus & 302 & $\mathrm{RdRp}$ & $\begin{array}{l}\text { FMV-s 5'-CGGTAGCAAATGGAATGAAA-3' } \\
\text { FMV-a5'-AACACTGTTTTTGCGATTGG-3' }\end{array}$ & Elbeaino et al., 2009 \\
\hline FLMaV-1 & Closterovirus & 352 & HSP70 & $\begin{array}{l}\text { FLMaV1-s5'-CGTGGCTGATGCAAAGTTTA-3' } \\
\text { FLMaV1-a 5'-GTTAACGCATGCTTCCATGA-3' }\end{array}$ & Elbeaino et al., 2006 \\
\hline FLMaV-2 & Ampelovirus & 360 & HSP70 & $\begin{array}{l}\text { FLMaV2-s 5'-GAACAGTGCCTATCAGTTTGATTTG-3' } \\
\text { FLMaV2-a 5'-TCCCACCTCCTGCGAAGCTAGAGAA-3' }\end{array}$ & Elbeaino et al., 2007 \\
\hline FMMaV & Closterovirus & 311 & HSP70 & $\begin{array}{l}\text { FMMaV-s 5'-AAGGGGAATCTACAAGGGTCG-3' } \\
\text { FMMaV-a 5'-TATTACGCGCTTGAGGATTGC-3' }\end{array}$ & Elbeaino et al., 2010 \\
\hline FLV-1 & Trichovirus & 389 & $\operatorname{RdRp}$ & $\begin{array}{l}\text { CPtr1-s 5'-CCATCTTCACCACACAAATGTC-3' } \\
\text { CPtr-a 5'-CAATCTTCTTGGCCTCCATAAG-3' }\end{array}$ & Gattoni et al., 2009 \\
\hline
\end{tabular}

\section{Cloning and sequencing}

Selected PCR products were ligated to pGEM-T Easy Vector $(50 \mathrm{ng} / \mu \mathrm{L})$ following the manufacturer's instructions (Promega), and then subcloned into Escherichia coli DH5 $\alpha$ cells. Plasmids were extracted from bacterial cells by the boiling method and further purified using polyethylene glycol as described in Sambrook et al. (1989). Plasmids containing PCR amplicons of expected sizes were subjected to automated bidirectional sequencing using virus-specific sense and antisense primers (PRIMM). Nucleotide and protein sequence homologies were analyzed using the online BLASTn analysis software.

\section{Electron microscopy}

\section{Virus particle purification}

The method described by Jensen et al. (1996) with some modification was used for virus purification. 250 grams of leaves from mosaic-diseased fig trees were homogenized in $0.1 \mathrm{M}$ phosphate buffer $\mathrm{pH} 7.0$ containing $0.5 \%$ mercaptoethanol, $450 \mu \mathrm{g}$ bentonite per milliliter and 0.01 M EDTA (3-4 ml of buffer for each gm of material). The juice was stirred overnight with gentle agitation, squeezed through two layers of cheesecloth, then clarified with $1 / 3$ volume cold chloroform, and centrifuged 10 minutes at $8000 \mathrm{rpm}$ in Sorvall GSA rotor. The virus suspension was stirred for a minimum of 1 hour, centrifuged for 10 minutes at $1000 \mathrm{rpm}$ in a Sorvall SA 600 rotor. The supernatant was resuspended in $2 \mathrm{ml}$ pad of $20 \%$ sucrose (w/v) in $1 \times$ SSC buffer $(0.15 \mathrm{M} \mathrm{NaCl}$, $0.015 \mathrm{M} \mathrm{Na}$ citrate, $\mathrm{pH} \mathrm{7.0)}$ and ultracentrifuged for 3 hours at $50,000 \mathrm{rpm}$ in a beckman Ti 70.1 rotor and pellets were resuspended in 1 x SSC buffer pH 7.0 was added to $1 \%$ Triton X-100 (v/v) with was stirred on ice for 30 minutes, followed by a low-speed centrifugation at $8000 \mathrm{rpm}$ for 10 minutes in an Eppendorf centrifuge 5415C. Sucrose gradients (10-40\%, $2 \mathrm{ml} /$ fraction) were prepared in the $1 \mathrm{x}$ SSC buffer and one $\mathrm{ml}$ of the homogenized pellet was layered over the sucrose columns and centrifugation at 35,000 rpm for 12 hours in a Beckman SW 41 rotor. The columns were fractionated manually in Eppendorf tubes $(1 \mathrm{~mL} /$ tube $)$ and subjected to spectrophotometry at 260 and $280 \mathrm{~nm}$. The resulted suspension was examined by electron microscopy.

\section{Leaf ultrastructure}

Samples were excised from infected fig leaves. Samples were rinsed several times in $4 \%$ glutaraldehyde in $0.05 \mathrm{M}$ phosphate buffer $(\mathrm{pH} 7.2)$, and kept overnight at $4^{\mathrm{O}} \mathrm{C}$. The specimens were post-fixed with $1 \% \mathrm{OsO}$ in $0.05 \mathrm{M}$ phosphate buffer for $2 \mathrm{hrs}$ at $4{ }^{\circ} \mathrm{C}$ and then washed two times with distilled water each for $15 \mathrm{~min}$. Samples were then dehydrated in a gradient acetone series, and embedded in Spurr (1969) medium. The selected sections were stained with a mixture of $2 \%$ uranyl acetate and acetone $(\mathrm{v} / \mathrm{v})$ for $20 \mathrm{~min}$. at room temperature followed by staining with reynolds lead citrate for $20 \mathrm{~min}$. The grids were then washed several times with d. $\mathrm{H}_{2} \mathrm{O}$ and dried on a filter paper. The dried grids were then examined under the electron microscopy (JEOL-CX100) in Electron Microscope Unit of Faculty of Science, Ain Shams University, Egypt.

\section{Negative staining}

Negative staining technique as described by Milne and Lesemann (1984). $15 \mu$ of purified suspensions of infected fig leaves were adsorbed on gold coated grids for 2 min followed by staining with $2 \%$ uranyl acetate $(\mathrm{w} / \mathrm{v})$, and washed with d. $\mathrm{H}_{2} \mathrm{O}$ to remove the excess stain. The grids were left for $5 \mathrm{~min}$ to dry and then examined by electron microscope.

\section{Production of virus free- fig plants}

\section{Establishment of meristem tip culture}

The shoot tip explants were collected from mature infected trees of fig (Ficus carica L) cvs. Asuani, Kadota, Black Mission, Kahramani, Sultani and AdasiAhmer in Aswan Governorate, Giza Governorate, Kaliobeya Governorate, Monoufia Governorate, Northern West Coast and Sinai Governorate, Egypt, respectively. The shoot tips were sterilized $2.5 \%$ sodium hypochlorite for 20 minutes for surface sterilization and washed 4-5 times with sterile water. The apical meristems with two or three leaf primordial were obtained under laminar air flow cabinet using a dissecting microscope. The explants were cultured on MS medium supplemented with $0.05 \mathrm{mg} \mathrm{L}^{-1} \mathrm{NAA}, 0.5 \mathrm{mg} \mathrm{L}^{-1}$ BAP and $0.5 \mathrm{mg}$ $\mathrm{L}^{-1}$ 2ip. After two months, numbers of shoots per plant were recorded, and the shoots were transferred on multiplication and rooting medium (Hemaid 2000; Hemaid et al., 2010). All cultures were incubated in the growth chamber at $26^{\circ} \mathrm{C}$, under 3000 lux light and 8 hours dark and $16 \mathrm{~h}$ light photoperiod conditions. The experiment was designed in a completely randomized experimental design with three replications and fifty explants included per replication.

\section{Immunization and polyclonal antiserum production}

Antiserum was prepared by injection a new zealant white rabbit with purified preparation according to Lister et al. (1983). Purified virus preparations containing nucleoprotein mixed 1:1 with Freund's incomplete adjuvant was injected subcutaneously to a New Zealand white rabbit, followed by four intramuscular injections over a period of four weeks. The FMV antiserum was obtained by bleeding the rabbit after 10 days of the last injection. The blood was incubated at $37^{\circ} \mathrm{C}$ for $1 \mathrm{hr}$. followed by centrifugation at $14,000 \mathrm{rpm}$ in GSA 
rotor at room temperature. The rough titre was determined by decorating virus particles (Milne, 1993; Seifers et al., 1997) with progressive antiserum dilutions.

\section{IgG purification}

The immunoglobulin $\mathrm{G}$ (IgG) fraction for the obtained antisera in this study was separated according to the technique described by (Mckinney and Parkinson, 1987; Temponi et al., 1989; Perosa et al., 1990). The IgG fraction was purified from rabbit sera with caprylic acid to precipitate albumin and other non- $\operatorname{IgC}$ proteins. Then, the IgG fraction is precipitated with ammonium sulfate. Equal volume of $120 \mathrm{mM}$ sodium acetate buffer ( $\mathrm{pH} 4.0)$ was added to the rabbit serum placed on the magnetic stirrer. Caprylic acid was slowly added with continuous stirring for $30 \mathrm{~min}$ at room temperature. The tubes were centrifuged at $5000 \mathrm{~g}$ for $10 \mathrm{~min}$ and the supernatant was saved. The supernatant was transferred to dialysis tubing and dialyzed versus PBS. The obtained IgG was further concentrated and purified by ammonium sulfate precipitation.

\section{Direct double antibody sandwich (DAS-ELISA)}

Direct double antibody sandwich (DAS-ELISA) demonstrated by Clark and Adams (1977) was used for detection of fig mosaic virus in plant tissue Polyethylene microtitre plates were coated with the specific immunoglobin $G$ (IgG) with $200 \mu \mathrm{l} /$ well diluted in coating buffer $\mathrm{pH}$ 9.6. Plates were washed three times, loaded with $200 \mu 1$ per well of extracted samples and incubated overnight at $4^{\circ} \mathrm{C}$. The wells were rewashed 3 times with PBS-tween 20, and $200 \mu \mathrm{l}$ of alkaline phosphatase conjugated antibodies were pipetted in each well and incubated at $37^{\circ} \mathrm{C}$ for 4 hours, then finally washed and revealed with $p$ nitrophenylphosphate substrate. Absorbance values were measured at $405 \mathrm{~nm}$ by the Bio-rad ELISA reader model 3550 at 15 min. intervals.

\section{Statistical analysis}

The experiment was carried out based on complete randomized design. Each of the experiments, excluding field performance study, was executed in five replicates with 20 samples per replication. Analysis of variance (ANOVA) was used to statistical analysis of experimental data using MSTAT Software (2009). Differences between individual means were estimated according to Snedecor and Cochran (1982). All values are reported as means \pm standard deviation.

\section{RESULTS AND DISCUSSION}

\section{Field survey and RT-PCR detection}

RT-PCR assays of samples yielded five DNA amplicons of sizes, $302 \mathrm{bp}, 352 \mathrm{bp}$, 360 bp, 311 bp and 389 bp, as results for FMV, FLMaV-1, FLMaV-2, FMMaV and FLV-1 infections, respectively (Figure 1). From a total of 300 samples, 252 $(84 \%)$ were infected by at least one virus. FLMaV-1 was the prevailing virus with an infection rate of $78.3 \%$ (Table 2). The incidence of this virus was particularly high on cvs. Sultani, Asuani and Adasi-Ahmer (100\%) grown in Northern West Coast, Aswan and Sinai province. While, the second virus for importance was FMV with an infection rate of $73.7 \%$, which occurred mainly on cv. Sultani $(100 \%)$ grown in Northern West Coast, on cv. Adasi-Ahmer (98\%) grown in Sinai province and on cv. Asuani (96\%) grown in Aswan province. FLMaV-2 ranked third as incidence $(50 \%)$ and was substantially equally distributed in all cultivars and regions (24-90\%) also the fourth virus for importance was FLV-1 (40.3\%), which occurred mainly on cvs. Sultani (94\%), Adasi-Ahmer (76\%) and Kadota (28\%), but was absent on cvs Black Mission, Kahramani and Asuani. While, FMMaV identical infection rates $(35 \%)$ and was consistently found in cvs. Sultani $(80 \%)$, Adasi-Ahmer $(60 \%)$, Asuani $(24 \%)$ Kadota (18\%), Kahramani (14\%) and Black Mission (12\%). A single FM tree was found infected with at least five viruses: FMV, FLMaV-1, FLMaV-2, FMMaV and FLV-1. The diversity of the viruses and their vectors reveal the complexity of the disease and the symptomatology observed in FM trees. The results show that the greatest level of infection in the assayed samples was attributed to FLMaV-1 not to FMV and that most fig trees are infected with two viruses in the North Coast region was $(100 \%)$ of Sultani cultivar. This result is not in agreement with other reports on the occurrence of fig virus infections where FMV has always been found to be the most widespread in mosaic diseased fig orchards (Hemaid, 2000; Castellano et al., 2007; Caglar et al., 2011; Shahmirzaie et al., 2012; El Air et al., 2015). These surveys showed that all five viruses characterized in this study were present in the main Egypt fig-growing areas, with levels of infections that were substantially in line with those reported from other Mediterranean countries with a few exceptions. In particular, the presence of FMV in fig trees was high $(73.7 \%)$ especially in the North Coas region was $(100 \%)$ of Sultani cultivar if compared to previous reports in Turkey (8.6\%) (Caglar et al., 2011), in Tunisian (37\%) (El Air et al., 2015) and Iran (7.6\%) (Shahmirzaie et al., 2012). While, The incidence of FLMaV-1 was particularly high $(78.3 \%)$, when compared with that reported from fig orchards of many surrounding countries, including Iran (11\%), Syria (4\%), Tunisia (33.3\%), Lebanon (15\%), Saudi Arabia (55\%) and Egypt (68.3\%) (Elbeaino et al., 2012;
Shahmirzaie et al., 2012; El Air et al., 2015; Amal et al., 2015). Also, the incidence of FLMaV-2 was high $(50 \%)$ than in other countries such as in Tunisia (4.3\%), Italy (45\%) and Lebanon (36.3\%) (Elbeaino et al., 2007; Amal et al. 2015). FMMaV was looked for in all the surveyed areas, its incidence was relatively lower $(35 \%)$ than in other countries such as in Tunisia $(60 \%)$ in cvs. Takelsa and Sfax (El Air et al., 2015) and high than that of Turkey (2\%) (Caglar et al., 2011). Finally, the incidence of FLV-1 was high (40.3\%) than that reported in Syria (40\%), Albania (17.5\%) and other Mediterranean countries (29.4\%) (Elbeaino et al., 2009b) and in Tunisia (4.3\%) (El Air et al., 2015).

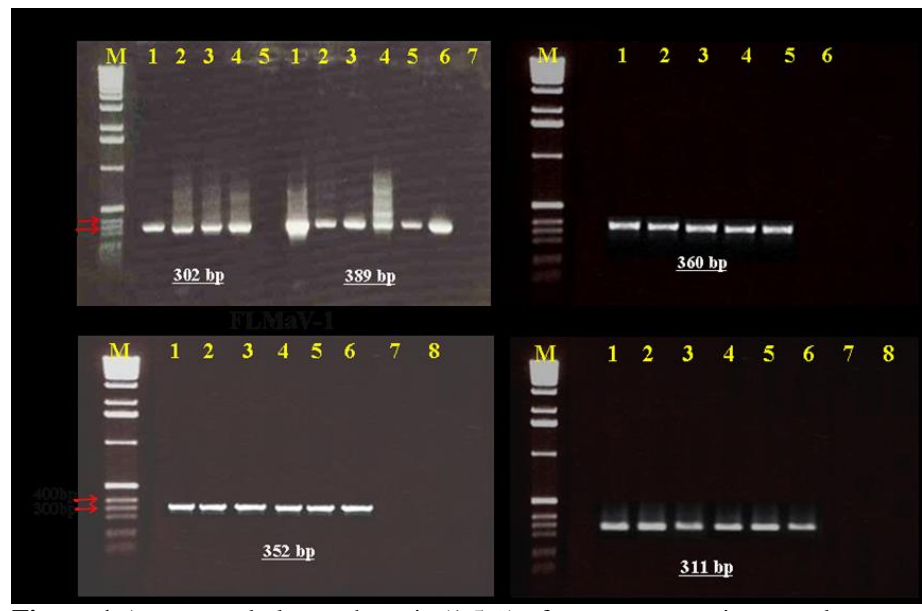

Figure 1 Agarose gel electrophoresis (1.5\%) of reverse-transcriptase polymerase chain reaction (RT-PCR) products amplified from infected fig plants. (FMV) lanes 1-4 are PCR-positive results from infected plants, Lane 5 is the PCRnegative from in vitro regenerated plants; (FLV-1 ) lanes 1-6 from infected plants and lane 7 from in vitro plant; (FLMaV-2) lanes 1-4 are PCR-positive results from infected plants, Lane 5 is the PCR-negative from in vitro regenerated plants lanes 1-5 are PCR-positive results from infected plants, Lane 6 is the PCRnegative from in vitro regenerated plants and (FLMaV-2 and FMMaV) lanes 16 are PCR-positive results from infected plants, Lanes 7-8 are the PCR-negative from in vitro regenerated plants. Lane M: DNA marker (1kb plus DNA ladder).
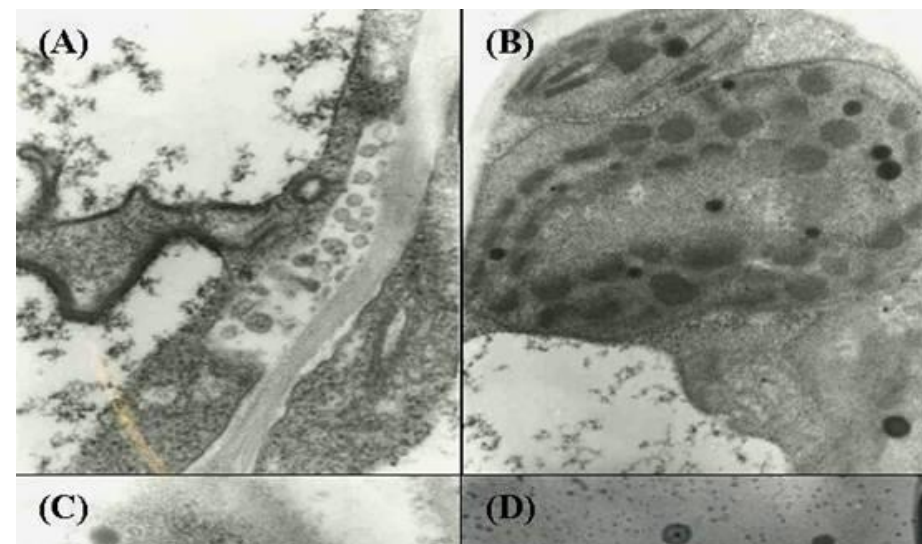

(D)

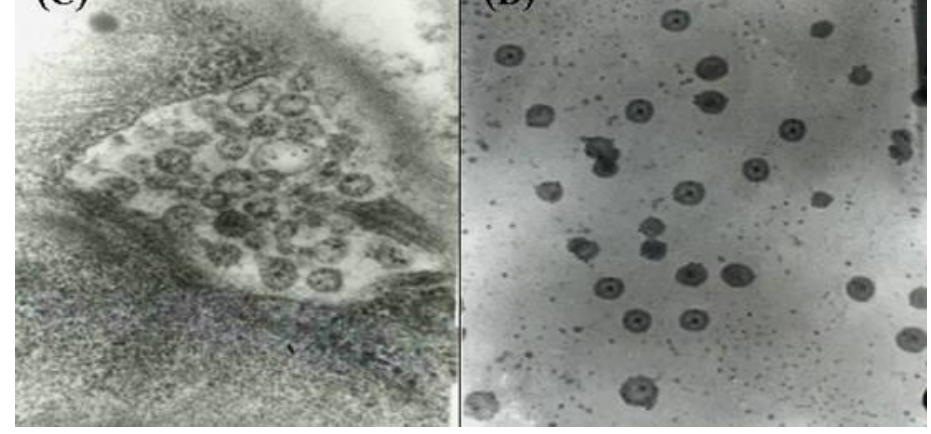

Figure 2 Electron micrographs of an ultra thin-section of infected fig leaves. (A and C): showed groups of Double-Membrane Particles (DMPs) cytoplasm of mesophyll cells, (B): in the chloroplast showing complete bold stain, and (D): showed a typical fig mosaic virus consisting of unique quasi-spherical from purified viral preparation. Bar: $300 \mathrm{~nm}$.

PCR amplification resulted in amplicons of the expected sizes (302 bp) of FMV, (352 bp) of FLMaV-1, (360 bp) of FLMaV-2, (311 bp) of FMMaV and (389 bp) of FLV-1 whose sequence identity with the nucleotide sequence. BLASTn analyses showed that sequences of FMV and FMMaV were $100 \%$ identical to the Italian (Genbank accession number AM941711and FJ611959), whereas 
similarities of FLMaV-1 (95-99\%), FLMaV-2 (97- 100\%) were found with the Italian (Genbank accession numbers AM113547, KC534878) and FLV-1 obtained sequence was deposited in the EMBL database under the accession No.
FN377573. The nucleotide sequence of these viruses was reported by (Elbeaino et al., 2007; Gattoni et al., 2009; Elbeaino et al., 2010; Ishikawa et al., 2012).

Table 2 Incidence of FMV, FLMaV-1, FLMaV-2, FMMaV and FLV-1 infections in fig cvs. Asuani, Kadota, Black Mission, Kahramani, Sultani and Adasi-Ahmer growing provinces of Egypt as determined by RT-PCR assays

\begin{tabular}{|c|c|c|c|c|c|c|c|c|c|c|c|c|c|}
\hline \multirow[t]{2}{*}{ Cultivar (Province) } & \multirow{2}{*}{$\begin{array}{l}\text { Tested tr } \\
\text { No. }\end{array}$} & \multicolumn{2}{|c|}{ Infected trees } & \multicolumn{2}{|c|}{ FMV } & \multicolumn{2}{|c|}{ FLMaV-1 } & \multicolumn{2}{|c|}{ FLMaV-2 } & \multicolumn{2}{|c|}{ FMMaV } & \multicolumn{2}{|c|}{ FLV-1 } \\
\hline & & No. & $\%$ & No. & $\%$ & No. & $\%$ & No. & $\%$ & No. & $\%$ & No. & $\%$ \\
\hline Asuani (Aswan) & 50 & 50 & 100 & 48 & 96 & 50 & 100 & 18 & 36 & 12 & 24 & 0 & 0 \\
\hline Kadota (Giza) & 50 & 32 & 64 & 19 & 38 & 15 & 30 & 12 & 24 & 9 & 18 & 14 & 28 \\
\hline Black Mission (Kaliobeya) & 50 & 30 & 60 & 15 & 30 & 22 & 44 & 20 & 40 & 6 & 12 & 22 & 0 \\
\hline Kahramani (Monoufia) & 50 & 40 & 80 & 40 & 80 & 48 & 96 & 19 & 38 & 7 & 14 & 0 & 0 \\
\hline Sultani (Northern West Coast) & 50 & 50 & 100 & 50 & 100 & 50 & 100 & 45 & 90 & 40 & 80 & 47 & 94 \\
\hline Adasi-Ahmer (Sinai) & 50 & 50 & 100 & 49 & 98 & 50 & 100 & 36 & 72 & 30 & 60 & 38 & 76 \\
\hline Total & 300 & 252 & 84 & 221 & & 235 & & 150 & & 104 & & 121 & \\
\hline Mean infection rate & & & 84 & & 73.7 & & 78.3 & & $\mathbf{5 0}$ & & 35 & & 40.3 \\
\hline
\end{tabular}

\section{Electron microscopy and cell ultrastructure}

Electron micrographs of sectioned cells prepared from FMD-infected $F$. carica $\mathrm{L}$. leaves represented in (Figure 2) showed the presence groups of doublemembrane particles (DMPs), considered to be FMV particles in parenchyma and subepidermical cells, always presented in rounded to ovoid $100-150 \mathrm{~nm}$ in size and elongated, straight to slightly flexuous up to or exceeding $1 \mu \mathrm{m}$ in length (Figures 2A and C). Moreover, long elongated and flexuous virus-like particles surrounding the chloroplast, in parenchyma cell also presented in Figure (2B) Also, large quasi-spherical double membrane-bound particles DMPs of 100 150 $\mathrm{nm}$ in diameter were showed in purified extracted from tissues having yellow mosaic and malformation (Figure 2D). This result is supported by (Appiano $\boldsymbol{e} t$ al., 1995; Elbeaino et al., 2009c; Alhudaib, 2012), they observed similar results for the infection with FMV results in distinct double-membrane bodies or particles, called DMBs or DMPs, 90-200 nm in diameter in the cytosol of infected parenchyma cells. Comparable large quasi-spherical DMBs of 100-150 $\mathrm{nm}$ in diameter were located in the cytoplasm of parenchyma cells. Electron dense median core particles were observed as well (Martelli et al., 1993)

\section{Meristem tip culturing for the elimination fig viruses}

Thirty meristems out of 180 were developed from the six cultivars that cultured on MS medium supplemented with $0.05 \mathrm{mg} \mathrm{L}^{-1} \mathrm{NAA}, 0.5 \mathrm{mg} \mathrm{L}^{-1} \mathrm{BAP}$ and 0.5 $\mathrm{mg} \mathrm{L}^{-1}$ 2ip (Figure 3A). The meristems commenced their initial growth by increasing in size and gradually changed to light green color; within 3-4 weeks small leaves appeared. After two months of incubation, the in vitro shoots that incubated with multiplication medium supplemented with $2 \mathrm{mg} \mathrm{L}^{-1}$ BAP and 0.5 $\mathrm{mg} \mathrm{L}^{-1} 2 \mathrm{iP}$ at 4 weeks (Figure 3B). The shoots transferred on rooting medium contained on $2 \mathrm{mg} \mathrm{L}^{-1}$ IBA and $0.5 \mathrm{mg} \mathrm{L}^{-1} \mathrm{NAA}$ of all cultivars were developed to plantlets that represent the six cultivars as shown in Figures $4 \mathrm{~A}$ and $\mathrm{B}$. The developed plantlets were studied for fig (Ficus carica L.) cvs. Asuani, Kadota, Black Mission, Kahramani, Sultani and Adasi-Ahmer as shown in Table (3). The highest response percentage of meristem explant forming shoots was in Sultani cultivar (100\%), Adasi-Ahmer cultivar, Asuani cultivar (99\%) and Kahraman cultivar $(96 \%)$. Also, the highest response of mean shoot length was in Asuani cultivar $(1.54 \mathrm{~cm})$, Adasi-Ahmer cultivar $(1.45 \mathrm{~cm})$ and Kadota cultivar $(1.35 \mathrm{~cm})$ compared with other cultivars. When shoots was transferred to multiplication medium the results showed that the highest response of mean number of shoots was in Kahramani (3.62) cultivar, Asuani (3.45) and Sultani (3.54) cultivars respectively. While, the Adasi-Ahmer cultivar showed the highest mean number of roots (3.25) followed by Sultani (2.95) and Black Mission (2.65) and the highest response of mean roots length was in Asuani (2.64) cultivar when transferred on root medium compared with other cultivars. Plants produced from the rooting stage were transfer to a greenhouse and they were repotted into sterile soil consists equal parts of peat and sand (v/v) (Figures 4C and 4D). In vitro propagation through meristem culture is the best possible means of virus elimination and produces a large number of plants in a short span of time. It is a powerful tool for large-scale propagation of horticultural crops including fig plants. Fig (Ficus carica L.) plantlets have been produced from shoot tips and meristem tips (Murithi et al., 1982; Demiralay et al., 1998; Gella et al., 1998; Hemaid 2000; Hepaksoy and Aksoy, 2006).

Table 3 In vitro developed fig (Ficus carica L.) cvs. Asuani, Kadota, Black Mission, Kahramani, Sultani and Adasi-Ahmer produced from meristem tips after eight weeks

\begin{tabular}{|c|c|c|c|c|c|c|}
\hline Cultivar & $\begin{array}{c}\% \text { of survived } \\
\text { meristems }\end{array}$ & $\begin{array}{l}\% \text { of meristems } \\
\text { forming shoots }\end{array}$ & $\begin{array}{l}\text { Mean shoots } \\
\text { length }(\mathrm{cm})\end{array}$ & $\begin{array}{c}\text { Mean number } \\
\text { of shoots }\end{array}$ & $\begin{array}{c}\text { Mean number } \\
\text { of roots }\end{array}$ & $\begin{array}{l}\text { Mean roots } \\
\text { length }(\mathrm{cm})\end{array}$ \\
\hline Asuani & 99 & 99 & $1.54 \pm 0.252^{\mathbf{a}}$ & $3.45 \pm 0.097^{\mathbf{c}}$ & $2.24 \pm 0.206^{\mathbf{f}}$ & $2.64 \pm 0.102^{\mathbf{a}}$ \\
\hline Kadota & 95 & 93 & $1.35 \pm 0.195^{\mathbf{c}}$ & $3.00 \pm 0.124^{\mathbf{d}}$ & $2.56 \pm 0.125^{\mathbf{e}}$ & $1.75 \pm 0.119^{\mathbf{b}}$ \\
\hline Black Mission & 90 & 87 & $1.04 \pm 0.095^{\mathbf{f}}$ & $2.95 \pm 0.078 \mathbf{e}$ & $2.78 \pm 0.115^{\mathbf{c}}$ & $1.54 \pm 0.145^{\mathbf{c}}$ \\
\hline Kahramani & 96 & 96 & $1.25 \pm 0.087^{\mathbf{d}}$ & $3.62 \pm 0.102^{\mathbf{a}}$ & $2.65 \pm 0.108^{\mathbf{d}}$ & $1.28 \pm 0.097^{\mathbf{f}}$ \\
\hline Sultani & 100 & 100 & $1.15 \pm 0.072^{\mathbf{e}}$ & $3.54 \pm 0.147^{\mathbf{b}}$ & $2.95 \pm 0.104^{\mathbf{b}}$ & $1.48 \pm 0.128^{\mathbf{e}}$ \\
\hline Adasi-Ahmer & 99 & 99 & $1.45 \pm 0.091^{\mathbf{b}}$ & $2.55 \pm 0.095^{\mathbf{f}}$ & $3.25 \pm 0.215^{\mathbf{a}}$ & $1.50 \pm 0.109^{d}$ \\
\hline
\end{tabular}

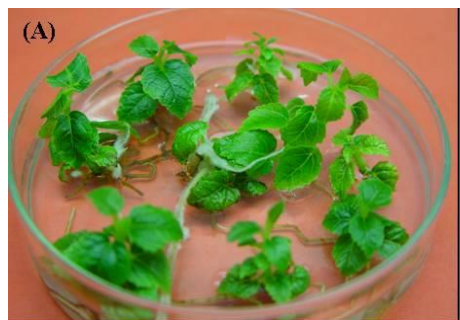

(B)

Figure 3 Fig regenerated plants from meristem tip culture on MS medium supplemented with $0.05 \mathrm{mg} \mathrm{L}^{-1}$ NAA, $0.5 \mathrm{mg} \mathrm{L}^{-1}$ BAP and $0.5 \mathrm{mg} \mathrm{L}^{-1} 2 \mathrm{ip}$ after two months (A); Shoot multiplication of Ficus carica L. cultivars on MS medium supplemented with $2 \mathrm{mg} \mathrm{L}^{-1} \mathrm{BAP}$ and $0.5 \mathrm{mg} \mathrm{L}^{-1} 2 \mathrm{iP}(\mathbf{B})$.

\section{Detection of FMV by DAS-ELISA}

Plantlets that are derived from tissue culture can be tested by DAS-ELISA. The fig samples were prepared $(0.2 \mathrm{~g}$ of fresh leaves in $2 \mathrm{~mL})$ and $200 \mu \mathrm{l} /$ well of each sample from fig (Ficus carica L) cvs. Asuani, Kadota, Black Mission,
Kahramani, Sultani and Adasi-Ahmer. The extraction of healthy fig plant tissues from in vitro plantlets used as negative control and the purified virus preparation were used as positive control. FMV-antiserum was produced from virus particles. The virus specific titer for the polyclonal rabbit antibodies raised against purified FMV was at least 1/1000. DAS-ELISA on leaves extracts from samples already tested in RT-PCR assay, using specific immunoglobin G ( $\operatorname{IgG}$ ) from bleeds diluted 1:1000 gave the optimal binding specificity. The extraction of the purified virus was used as positive control. The results indicated that most infected trees gave positive results with FMV antiserum diluted 1:1000 while healthy tissues from in vitro plantlets gave negative results. Our results indicated that samples taken from the in vitro regenerated cultivars showed not any color, whereas, all the infected field samples (symptoms showing) developed yellow color after DAS-ELISA test. This indicated that the antiserum reacted strongly with all infected plants, but the in vitro regenerated plantlets did not react. This may be due to the regenerated plantlets becoming $100 \%$ free from fig mosaic virus through meristem culture. This result is supported by Hemaid (2000), in which similar results were observed for the detection of fig mosaic virus through DASELISA test. 


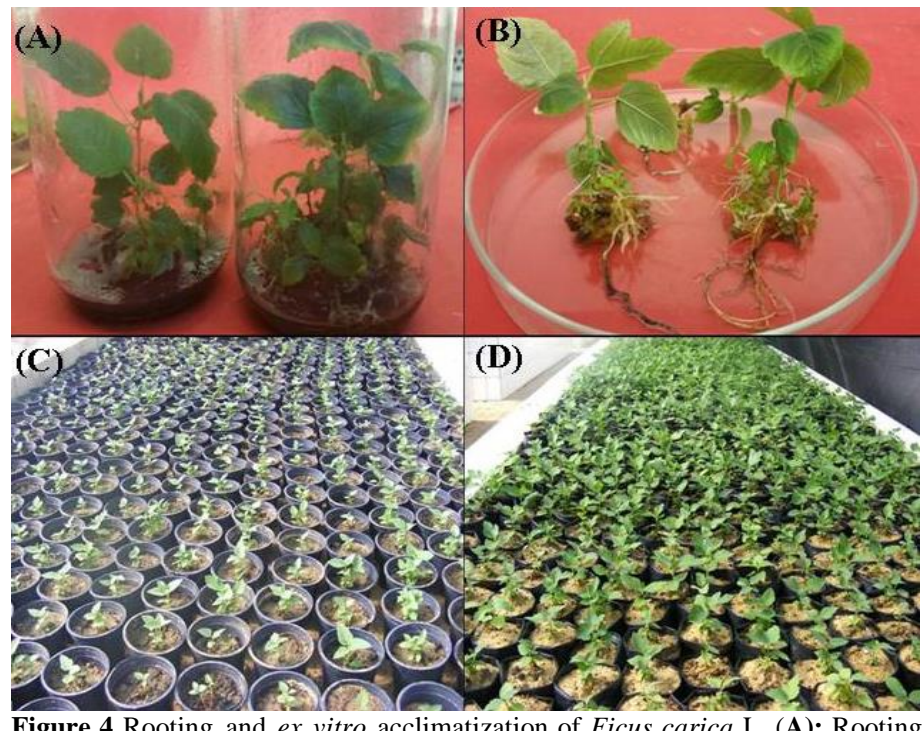

Figure 4 Rooting and ex vitro acclimatization of Ficus carica L. (A): Rooting of Ficus carica L. on MS medium supplemented with $2 \mathrm{mg} \mathrm{L}^{-1} \mathrm{IBA}$ and $0.5 \mathrm{mg}$ $\mathrm{L}^{-1}$ NAA, (B): healthy plantlets with normal roots, (C): Acclimatization of Ficus carica L. plants after three weeks and (D): fig seedlings after two months.

\section{CONCLUSION}

Fig (Ficus carica L.) is one of the old and the most common fruit tree grown in all the Mediterranean countries, particularly in Egypt for which no information was previously available. A recent investigation indicated that fig mosaic disease was the main pathogenic agent. In this study, field surveys were conducted in the areas of Northern West Coast, Aswan, Kaliobeya, Monoufia, Giza and Sinai Governorate to detect any of FMV, FLMaV-1, FLMaV-2, FMMaV and FLV-1. This is the first report of this virus occurring in the Egyptian fig orchards in most governorates of Egypt.In addition to that, a total 300 fig samples were collected from the surveyed areas. Molecular studies, by using RT-PCR were detected in test samples with overall incidence of $(84 \%)$. The most spread virus was FLMaV-1 (78.3) and FMV (73.7\%), flowed by FLMaV-2 (50\%), FLV-1 $(40.3 \%)$ and FMMaV (35\%). Also, were detecting about $100 \%$ of mixed infection between FLMaV-1 and FMV in some areas. Portions of the fig virus's genomes were sequenced and showed high similarity with published ones in GenBank (98$100 \%)$. FMV-antiserum was produced from virus particles. Symptomatology identification of FMV was recorded in the infected samples that judged by DASELISA as mosaic symptoms observed in almost all growing areas of Egypt. The results of DAS-ELISA on leaves extracts from fig samples already tested in RTPCR assay, using IgG purified from blood, showed that the IgG obtained from blood diluted 1:1000 gave the optimal binding specificity and confirmed the molecular assays. Tissue cultured plantlets were established from these plants and used to determine the effectiveness of various methods for detecting a virus in in vitro cultured fig plants.

Acknowledgments: The author is thankful to the Tissue Culture and Biotechnology Labs., Maryout Research Station, Desert Research Center, Alexandria, Egypt.

\section{REFERENCES}

Acikgöz, S., Döken, T. (2003). The determination of sampling time for dsRNA isolation of the agent of fig mosaic disease prevalent in Aegean region: Turkey. Acta Horticulturae, 605:307-310. https:// 10.17660/ActaHortic.2003.605.46.

Adams, M.J., Carstens, E.B. (2012). Ratification vote on taxonomic proposals to the international committee on taxonomy of viruses. Archives of Virology, 157:1411-1422. https://doi: 10.1007/s00705-012-1299-6.

Amal, Y. A., Esam K.F. E., Areej A. B., Toufic E. (2015). Four viruses infecting figs in Western Saudi Arabia. Phytopathologia Mediterranea, 54, 3, 497-503. https://doi.org/ 10.14601/Phytopathol Mediterr-16318.

Alhudaib, K. (2012). Incidence of fig leaf mottle-associated virus and fig mosaic virus in Eastern province of Saudi Arabia. International Journal of Virology, 8 128-132. https://doi.org/10.3923/ijv.2012.128.132.

Appiano A.M., Conti, M., Zini, N. (1995). Cytopathological study of the doublemembrane bodies occurring in fig plants affected by fig mosaic disease. Acta Horticulturae, 386, 585-592. https://doi.org/10.17660/ActaHortic. 1995.386.86.

Blodgett, E. C., Belgin, Gomec. (1967). Fig mosaic. Plant Disease Report, 51:893-896.

Caglar, B.K., Fidan, H., Guldur, M.E., Elbeaino, T. (2011). The prevalence of three viruses infecting fig in southern Turkey. Journal of Phytopathology 159, 181-183. https://doi.org/10.1111/j.1439-0434.2010.01749.x.
Caglayan, K., Medina, V., Gazel, M., Serce., C., Serrano, L. (2009). Putative agents of fig mosaic disease in Turkey. Turkish Journal of Agriculture \& Forestry, 33: 469-476. https://doi.org/10.3906/tar-0807-20.

Castellano, M.A., Gattoni, G., Minafra, A., Conti, M., Martelli, G.P. (2007). Fig mosaic in Mexico and South Africa. Journal of Plant Pathology, 89, 441-443. http://www.sipav.org/main/jpp/volumes/0307/030720.pdf.

Clark, M.F., Adams A. N. ( 1977). Characteristics of the microplate method of enzyme - linked immunosorbent assay for the detection of plant viruses. Journal of General Virology, 34: 475 - 483. http://doi: 10.1099/0022-1317-34-3-475.

Clark, M.F., M. Bar-Joseph. (1984). Enzyme immunosorbent assays in plant virology. Pages 51-85 in Methods in virology, edited by K. Maramorosch and $\mathrm{H}$ Koprowski. Academic Press, New York, USA. https://doi.org/10.1016/B978-012-470207-3.50009-7.

Condit, I. J., Home, W. T. (1933). A mosaic of the fig in California Phytopathology, 23:887-896.

Cooper, J.I., Edwards, M.L. (1986). "Variations and limitations of enzymeamplified immunoassays", Developments and applications in virus testing, edited by R.A.C. Jones and L. Torrance. Association of Applied Biologists, Wellesbourne, UK, pp.139-154.(16) Polyclonal and Monoclonal Antibody-Based Methods for Detection of Plant Viruses. Available from: https://www.researchgate.net/publication/283344435

Polyclonal and Monoclonal Antibody-

Based Methods for Detection of Plant Viruses.

Demiralay, A., Yalçin-Mendi, Y., AkaKaçar,Y., Cetiner, S. (1998). In vitro propagation of Ficus carica L. var. Bursa Siyahi through meristem culture. Acta Horticulturae, 480: 165-167. http://doi: 10.17660/ActaHortic.1998.480.28.

ElAir, M., Mahfoudhi, N., Digiaro, M., Dhouibi, M.H., Elbeaino, T. (2015).

Incidence and distribution of viruses in Tunisian fig orchards. Journal of Plant Pathology, 97:327-331. http://doi: 10.4454/JPP.V97I2.030.

Elbeaino, T., Digiaro, M. De Stradis, A., Martelli, G.P. (2006). Partial characterization of a closterovirus associated with a chlorotic mottling of fig. Journal of Plant Pathology, 88, 187-192. http://www.sipav.org/main/jpp/volumes/0206/020608.pdf.

Elbeaino T., Digiaro, M., De Stradis, A., Martelli, G.P. (2007). Identification of a second member of the family Closteroviridae in mosaic-diseased figs. Journal of Plant Pathology, 89, 119-124. http://www.sipav.org/main/jpp/volumes/0107/010714.pdf.

Elbeaino, T., Digiaro, M., Alabdullah, A., De Stradis, A, Minafra, A., Mielke, N. Castellano, M.A., Martelli, G.P. (2009a). A multipartito single-stranded negativesense RNA virus is the putative agent of fig mosaic disease. Journal of General Virology, 90:1281-1288. http://doi: 10.1099/vir.0.008649-0.

Elbeaino, T., Digiero, M., Martelli, G.P. (2009b). Complete nucleotide sequence of four RNA segments of fig mosaic virus. Archives of Virology, 154:1719-1727. http://doi: 10.1007/s00705-009-0509-3.

Elbeaino T., Nahdi, S., Digiaro, M., Alabdullah, A., Martelli, G.P. (2009c) Detection of Fig leaf mottle-associated virus1and Fig leaf mottle-associated virus 2 in the Mediterranean region and study on sequence variation of the HSP70 gene. Journal of Plant Pathology, 91, 425-431. http://sipav.org/main/jpp/index.php/jpp/article/download/973/759.

Elbeaino, T., Heinoun, K., Digiaro, M., Martelli, G.P. (2010). Fig mild mottleassociated virus, a novel closterovirus infecting fig. Journal of Plant Pathology 92,165-172. http://www.sipav.org/main/jpp/volumes/0110/011017.pdf.

Elbeaino T., Abou Kubaa, R., Digiaro, M., Minafra, A., Martelli, G.P. (2011a) The complete nucleotide sequence and genome organisation of fig cryptic virus, a novel bipartite dsRNA virus infecting fig, widely distributed in the Mediterranean basin. Virus Genes, 42, (3), 415-421. http://doi:10.1007/s11262011-0581-0.

Elbeaino T., Digiero, M., Martelli, G.P. (2011b). The complete sequence of Fig fleck-associated virus, a novel Tymoviridae member infecting fig. Virus Research, 161, 198-202. https://doi.org/10.1016/j.virusres.2011.07.022.

Elbeaino T., Abou Kubaa, R., Ismaeil, F., Mando, J., Di-giaro, M. (2012) Viruses and hop stunt viroid of fig trees in Syria. Journal of Plant Pathology, 94 (3),

$687-691$

http://www.plantprotection.pl/PDF/56(2)/JPPR 56(2)_03 Alimoradian.pdf

Flock, R. A., Wallace, J. M. (1955). Transmission of fig mosaic by the eriophyid mite Aceria ficus. Phytopathology, 45:52-54

Gattoni G., Minafra, A., Castellano, M.A., De Stradis, A., Boscia, D., Elbeaino, T., Digiero, M., Martelli, G.P. (2009). Some Properties of Fig latent virus1, a new member of the family Flexiviridae. Journal of Plant Pathology, 91, 543552. http://www.jstor.org/stable/41998672?seq=1\#page scan tab contents.

Gella, R., Marin, J. A., Corrales, M. L., Toribio, F. (1998). Elimination of fig mosaic from shoot tip cultures by thermotherapy. Acta Horticulturae, 480: 173177. http://doi: 10.17660/ActaHortic.1998.480.30.

Hemaid, I. A. Soliman (2000). Tissue culture technique for production virus free fig and its in vitro preservation .M.Sc. Thesis, Fac. of agric., Cairo Univ., Egypt. $\mathrm{P}(143)$

Hemaid, I. A. Soliman, Mahdia, F. G., Naglaa, A. A., (2010). Efficient transformation and regeneration of fig (Ficus carica L.) via somatic embryogenesis. Genetic Modified Crops and Food (GM crops\& food), January/February 1:1, 47-58. http://dx.doi.org/10.4161/gmcr.1.1.10632. 
Hepaksoy, S., Aksoy, U. (2006). Propagation of Ficus carica L. Clones by In vitro Culture. Biologia Plantarum, 50: 433-436. https://doi.org/10.1007/s10535006-0063-8.

Ishikawa, K., Maejima, K., Komatsu, K., Kitazawa, Y., Hashimoto, M., Takata, D., Yamaji, Y., Namba, S. (2012). Identification and characterization of two novel genomic RNA segments of fig mosaic virus, RNA5 and RNA6. Journal of General Virology, 93:1612-1619. http:// doi: 10.1099/vir.0.042663-0.

Ishikawa, K., Maejima, K., Komatsu, K. (2013). Fig mosaic emaravirus p4 protein is involved in cell-to-cell movement. Journal of General Virology, 93 (3): 682-686. http:// doi: 10.1099/vir.0.047860-0.

Jensen, S.G., Lane , L.C., Seifers, D.L. (1996). A new disease of maiza and wheat in the high plains. Plant Disease, 80: 1387-1390. https://gd.eppo.int/download/doc/1044_minids_WHPV00.pdf.

Lister, R. M., Hammond, J., Clements, D.L. (1983). Comparison of interadermal and intermuscular injection for raising plant virus antisera for use in Elisa. Journal of Virological Methods, 6:179. https://doi.org/10.1016/01660934(83)90030-7.

Martelli G.P., Castellano, M.A., Lafortezza, R. (1993). An ultrastructural study of fig mosaic. Phytopathologia Mediterranea 32, 33-43. http://www.jstor.org/stable/42685978.

Mckinney, M.M., Parkinson, A. (1987). A Simple, Non-Chromatographic Procedure To Purify Immunoglobulins From Serum And Ascites Fluid.J. Immunol. Methods. 96: 271-278. https://doi.org/10.1016/0022-1759(87)90324-3. Milne, R.G., Lesemann, O. E. (1984). Immunosorbent electron microscopy in plant virus studies. Methods in Virology VIII: 85-101. https://doi.org/10.1016/B978-0-12-470208-0.50009-8.

Milne, R.G. (1993). Electron microscopy of in vitro preparations. In: Matthews, R.E.F. (Eds.): Diagnosis of Plant Virus Diseases, 215-131. CRC Press, Boca Raton, FL, USA.

Murithii, L.M., Rangan, T.S., Waite, B. H. (1982). In vitro propagation of fig through shoot tip culture. Hortiscience. 17 (1): 86-87.

Perosa F, Carbone R, Ferrone S, Dammacco F. (1990). Purification of human immunoglobulins by sequential precipitation with Caprylic Acid and Ammonium Sulphate. Journal of Immunological Methods, 128: 9-16. https://doi.org/10.1016/0022-1759(90)90458-8.

Sambrook, J., Fritsch, E.F., Maniatis, T. (1989). Molecular cloning, vol 2. Gold Spring Harbor Laboratory Press, New York https://trove.nla.gov.au/version/180145381.

Seifers, D.L., Horvey, T.L., Martin , T.J., Jensen , S.G. (1997). Identification of the Wheat Curl mite as the vector of the High plains virus of corn and wheat. Plant Disease, 81:1161-1166. https://doi.org/10.1094/PDIS.1997.81.10.1161.

Serrano, L., Ramon, J., Segarra, J., Medina, V., Achón, M.A., López, M., Jua'rez, M. (2004). New approach in the identification of the causalagent of fig mosaic disease. Acta Horticulturae, 657:559-566. https://doi 10.17660/ActaHortic.2004.657.91.

Shahmirzaie, M., Rakhshandehroo, F., Zamani Zadeh, H. R., Elbeaino, T. (2012) Current status of fig mosaic disease in Iran. Journal of Phytopathology, 160: 324-330. https://doi.org/10.1111/j.1439-0434.2012.01908.x.

Snedecor, G.W., Cochran, W.G. (1982). Statistical Methods. 7th Edition, Iowa State University Press, Towa, 511. https://doi.org/ 10.2307/2530332.

Spurr, A R. (1969). A low-viscosity epoxy resin embedding medium for electron microscopy, J. Ultrastruct. Res., 26:31-43. https://doi.org/10.1016/S00225320(69)90033-1.

Temponi, M., Kageshita, T., Perosa, F., Ono, R., Okada, H., Ferrone, S. (1989) Purification Of Murine Igg Monoclonal Antibodies by Precipitation With Caprylic Acid: Comparison With Other Methods of Purification. Hybridoma, 8:85-95. https://doi.org/10.1089/hyb.1989.8.85.

Tzanetakis, I.E., Laney, A.G., Keller, K.E., Martin, R.R (2010). New viruses found in fig exhibiting mosaic symptoms. $21^{\text {st }}$ International Conference on Virus and other Graft Transmissible Diseases of Fruit Crops. Julius-Kühn-Archiv, 427. https://naldc.nal.usda.gov/download/47395/PDF.

Van Regenmortel, M.H.V., Dubs, M.C. (1993). Van Regenmortel, M.H.V., Dubs, M.C. (1993). Serological procedures. In : "Diagnosis of Plant Virus Diseases" (Matthews R.E.F., ed.), CRC Press, pp. 159-214

Walia, J.J., Salem, N.M., Falk, B. M. (2009). Partial sequence and survey analysis identify a multipartite, negative-sense RNA virus associated with fig mosaic. Plant Disease, 93 (1): 1-10. https://doi.org/10.1094/PDIS-93-1-0004.

Walia, J. J., Falk, B.W. (2012). Fig mosaic virus mRNAs show generation by $\begin{array}{llll}\text { cap-snatching. Virology } 426 & \text { (2): } 162-166 . & \text { https://doi: }\end{array}$ 10.1016/j.virol.2012.01.035 